\title{
LA VIOLENCIA COTIDIANA COMO MECANISMO DE INTEGRACIÓN Y ASCENSO SOCIAL. EL CASO DE AREQUIPA A FINES DEL VIRREINATO.
} 1784-1824.

\section{THE DAILY VIOLENCE AS A MECHANISM OF SOCIAL ASCENT. THE CASE OF AREQUIPA AT THE END OF THE VICEROYALTY. 1784-1824.}

\author{
César Belan \\ Universidad Católica San Pablo \\ Orcid: 0000-0002-1030-066X
}

\section{Resumen:}

El presente artículo analiza el delito de injurias enmarcado en la sociedad arequipeña de fines del s. XVIII. Utilizando algunos conceptos de la teoría social de Erving Goffman pretende buscar la racionalidad política detrás de las injurias y los procesos judiciales derivados de ellos, apuntando como estos mecanismos eran utilizados como medios de integración y ascenso social en la ciudad. Asimismo, se pretende describir el ideal de ciudadano como oposición a las conductas sociales reprochadas en las causas de injurias. Palabras clave: Injuria; ascenso social; racismo; blanqueamiento mental.

\begin{abstract}
:
This article analyzes the crime of insults framed in Arequipa society at the end of s. XVIII. Using some concepts of the social theory of Erving Goffman seeks study the political rationality behind the insults and the trials derived from them, pointing out how these mechanisms were used as means of social advancement in the city. This article also describes the archetype of citizen in Arequipa, in opposition to the social behaviors mislabeled in the causes of insults.
\end{abstract}

Keywords: Injuries; social advancement; racism; honor. 


\section{AMERICANISTAS}

\section{César Belan}

La violencia cotidiana como mecanismo de integración y ascenso social. El caso de Arequipa a fines del Virreinato. 1784-1824.

\section{ISSN 1988-7868}

\section{Arequipa a fines del virreinato: Isonomía y movilidad social.}

Arequipa, ciudad emplazada en el valle interandino del río Chili a 2300 metros sobre el nivel del mar, fue convirtiéndose progresivamente desde su fundación en 1540 en uno de los ejes más importantes del sur andino. Este proceso de ascenso económico y político de la ciudad tuvo su culmen en el siglo XVIII. Las reformas borbónicas impulsaron la economía de la región de forma acelerada y sostenida, gracias a una producción vitivinícola que se destinaba al mercado de los centros mineros como Potosí y, en menor medida, a Tarapacá y Caylloma. ${ }^{1}$ Este auge no se desaceleraría aún en la turbulenta coyuntura de las Guerras de Independencia. ${ }^{2}$ El desarrollo económico fue, en ese siglo, acompañado del reconocimiento de la preponderancia política de la urbe arequipeña. Así pues, en 1782 se establecería en la ciudad la sede de la Intendencia de Arequipa, jurisdicción que incluía los actuales departamentos de Arequipa, Moquegua, Tacna en el Perú y las regiones de Tarapacá y Arica en la actual Chile.

La bonanza y prosperidad lograda en el s. XVIII atrajo migración en todos los niveles hacia Arequipa. La pequeña élite local se reconfiguraría y consolidaría su poder económico y político al entroncarse con cántabros y sobre todo vascos quienes, a instancias de la Corona, se establecieron en la ciudad, ocupando puestos importantes en el gobierno y el comercio local. Las redes sociales, experiencia mercantil y activa participación en la administración por parte de los recién llegados, permitió un mejor aprovechamiento del patrimonio de los antiguos vecinos, dinamizándose así la economía en la región. ${ }^{3}$

\footnotetext{
${ }^{1}$ Kendall Brown, Borbones y aguardiente. La reforma imperial en el sur peruano: Arequipa en vísperas de la independencia. Lima: Banco Central de Reserva del Perú e Instituto de Estudios Peruanos, 2008; Carlos Buller, Vinos, aguardiente y mercado. Auge y declive de la economía del vino en los valles de Arequipa (1770-1853). Lima: Quellca y Centro de Estudios Andinos, 2011.

${ }^{2}$ Víctor Condori, Cuadernos de Historia de Arequipa. Cambio político y crisis económica en Arequipa a inicios de la República. 1825-1827. Arequipa: Ediciones Rhojita, 2012.

3 Antonio Unzueta Echeverría, "Los vascos de Arequipa y la cofradía y capilla de Nuestra Señora de Aránzazu". En: Oscar Álvarez Gila e Idoia Arrieta (eds.), Las huellas de Aranzazu en América. Primer Congreso Internacional Arantzazu y los franciscanos vascos en América. Donostia-San Sebastian: Eusko Ikaskuntza, 2004, p. 115-137; Eusebio Quiroz Paz-Soldán, "Inmigración Vasca a Arequipa". En: Giovanni Bonfiglio (ed.), La Presencia Europea en el Perú. Lima: Fondo Editorial del Congreso del Perú, 2001.
} 


\section{AMERICANISTAS}

\section{César Belan}

La violencia cotidiana como mecanismo de integración y ascenso social. El caso de Arequipa a fines del Virreinato. 1784-1824.

\section{ISSN 1988-7868}

El sector plebeyo se benefició también por la bonanza, lo que generó también migración hacia la ciudad por parte de ese conglomerado. Un buen número de mestizos o de indígenas altamente hispanizados se trasladaron a tierras arequipeñas. La necesidad de mano de obra para la reedificación de la ciudad luego de los frecuentes y sucesivos terremotos que se dieron desde el s. XVII, y el declive del Cuzco como centro económico y político a causa de su bajo rendimiento agrícola, la peste de 1720 y la revuelta tupacamarista, fueron algunas de las causas de la migración a la ciudad. Al respecto, el clérigo y cronista Ventura Travada y Córdova (1752) señaló: «se va extendiendo tanto el vecindario, mayormente de forasteros, que vienen atraídos de las vitalidades que hallan en la ciudad y su comercio, que en breve volverán a retirar más el rollo para dar más ensanche a la ciudad». ${ }^{4}$

La ciudad estaba compuesta por una población predominantemente hispánica -en el extremo cultural del término - que se concentraba en el numeroso sector criollo y mestizo. Según la Relación de gobierno del intendente, en 1792 el $71 \%$ de los habitantes de la ciudad y el $60 \%$ de los pobladores del partido eran considerados españoles ${ }^{5}$, números muy resaltables si se los compara con el panorama demográfico de otras intendencias.

Este grupo, en su mayoría, conformaba una pequeña burguesía urbana de modestos recursos, conformada por propietarios de pequeñas parcelas (cercanas a la ciudad y las aldeas que las circundaban) que abastecían de alimentos a la población, explotadas por ellos mismos y sus familias. Otros se dedicaban al comercio, actividades artesanales y diversos oficios como tenderos, pulperos, notarios, agrimensores, clérigos y abogados. Este sector es catalogado por algunos estudiosos como pequeña burguesía o

Carlos Malamud, "La consolidación de una familia de la oligarquía arequipeña: Los Goyeneche”. Quinto Centenario, $\mathrm{n}^{\circ} 4$ (Madrid, 1982), pp. 49-135.

${ }^{4}$ Ventura Travada y Córdova, El suelo de Arequipa convertido en cielo por Dr. Ventura Travada y Córdova cura que fue de las doctrinas de Salamanca y Pocsi de la misma diocesis. 1752. Arequipa: Primer festival del libro arequipeño, 1958, tomo 1, p. 83.

${ }^{5}$ John Fisher, Arequipa 1796-1811. La relación de gobierno del Intendente Salamanca. Lima: Seminario de Historia Rural Andina / Universidad Nacional Mayor de San Marcos (UNMSM), 1968, p. 274. 


\section{AMERICANISTAS}

\section{César Belan}

La violencia cotidiana como mecanismo de integración y ascenso social. El caso de Arequipa a fines del Virreinato. 1784-1824.

\section{ISSN 1988-7868}

sector intermedio. ${ }^{6}$ No obstante, preferimos designarlo como plebe mesocrática, ya sea por la paridad económica entre esta pequeña burguesía propietaria y lo que la historiografía conoce comúnmente por plebe, o por la gran movilidad social de la ciudad hacía que los miembros de esta clase se convirtieran en plebe o viceversa.

De igual manera, podemos diferenciar a un sector plebeyo de segundo orden, plebe propiamente dicha, o ínfima plebe, tal como era clasificada en los papeles judiciales y administrativos. Este grupo estaba también compuesto por criollos y mestizos, pero fundamentalmente por indígenas altamente hispanizados ${ }^{7}$ y pardos libres. Estrato que, como hemos dicho, se diferenciaba poco del estrato la plebe mesocrática, ya sea por el modesto patrimonio que ésta poseía, ya sea por las amplias posibilidades de movilidad social que ofrecía Arequipa a finales del XVIII. Más deprimidos económicamente, los integrantes de este sector contaban únicamente con su fuerza de trabajo, la que utilizaban (conjuntamente con los esclavos) efectuando las tareas más pesadas como la servidumbre doméstica, el trabajo de peón agrícolas, albañil, aprendiz de oficios, etc. Los miembros de este estrato, especialmente los indígenas, se dedicaban a la confección de humildes telas y prendas de lienzo burdo de algodón conocido como «tocuyo». ${ }^{8}$

Luego, y como se ha adelantado, los documentos notariales atestiguan que las diferencias económicas entre la élite, la plebe mesocrática y la ínfima plebe de la ciudad

\footnotetext{
${ }^{6}$ Sarah Chambers, De súbditos a ciudadanos: Honor, género y política en Arequipa, 1780-1854. Lima: Red para el desarrollo de las ciencias sociales en el Perú y Pontificia Universidad Católica del Perú, 2003, p. 70 y s; Ramón Gutiérrez, Evolución Histórica Urbana de Arequipa (1540-1990). Lima: Facultad de Arquitectura, Urbanismo y Artes, Universidad Nacional de Ingeniería, 1992, p. 66 y s; Fernando Calderón, La dulce metamorfosis Movilidad y reproducción social: la familia Tristán y las élites del surandino durante el siglo XVIII, Tesis de doctorado no publicada, Colegio de México, 2019, p. 71.

${ }^{7}$ «No se habla otra lengua que la castellana. [...] Los indios de este pueblo, apenas se distinguen de los españoles; son muy la [borrado] y racionales; y asi ellos como ellas visten el mismo trage que los Españoles». Francisco Javier de Echevarría, "Descripción sobre el pueblo de Cayma: Un documento de principios del siglo XIX (Arequipa, 1804)”. Historia y Región, n² 2, (Lima, 2014), p. 250.

Carlos Maitza Ozcoidi, "La definición del concepto del honor. Su entidad como objeto de investigación histórica”. Espacio, Tiempo y Forma, Serie IV, Historia Moderna, n8 (Madrid,1995), pp. 191-209.

${ }^{8}$ Víctor M. Barriga, Memorias para la Historia de Arequipa. Relaciones de la visita al Partido de Arequipa realizada por el Gobernador Intendente don Antonio Álvarez y Jiménez 1786-1791. Arequipa: Editorial La Colmena S.A, 1941, tomo 1, p. 52 y ss.
} 


\section{AMERICANISTAS}

\section{César Belan}

La violencia cotidiana como mecanismo de integración y ascenso social. El caso de Arequipa a fines del Virreinato. 1784-1824.

\section{ISSN 1988-7868}

no eran tan marcadas. Como se ha mencionado en otra oportunidad ${ }^{9}$ la gran mayoría de las casonas de la ciudad fueron subdivididas y arrendadas, interactuando e integrándose en ellas varias capas sociales. ${ }^{10}$ La pérdida de capital y capacidad económica producida por las eventuales crisis y la propia dinámica mercantil, hacían que muchas familias que antes ostentaban algún lustre en su origen terminaran compartiendo espacio y formas de vida de indígenas asentados en la ciudad y mestizos prósperos. Sin embargo, siempre sacaban a relucir su antigua posición y el capital simbólico que poseían. Son varios los testimonios judiciales en que "dones y doñas", hijas y viudas de "antiguos vecinos y capitanes" piden se les considere pobres de solemnidad y se les dispense de tasas. ${ }^{11}$

Asimismo, prácticamente, no existía latifundio en las tierras cercanas a la ciudad, habiéndose consolidado el minifundio en la ciudad y sus anexos hasta bien entrado el s. XX. Finalmente, Arequipa no poseía una élite importante, ni en ella se corroboraban cuadros de miseria como en México o Lima. ${ }^{12}$ En ese sentido, Calderón afirmará que en Arequipa:

los elementos que distinguían a la élite como: la propiedad urbana y rural, la participación en el cabildo, los donativos al rey y a la Iglesia, la fundación de capellanías y otros vínculos; se propagaron entre las familias arequipeñas, aunque

\footnotetext{
${ }^{9}$ César Belan, "Un espacio libre de bandidos: Topografía delictiva de la intendencia de Arequipa (17801824)". En: Carlos Mata, Antonio Sánchez y Maritina Vinatea (eds.) La escritura del territorio americano. Nueva York: Instituto de estudios auriseculares (IDEA), 2019, pp. 27-43.

${ }^{10}$ Algo similar ocurrió en el barrio de Cocharcas, en Lima: "Todos se encontraban juntos, compartiendo los mismos espacios. Esto debió impactar sobre las relaciones cotidianas entre los individuos pues al no existir barreras bien marcadas para diferenciar los estamentos, era necesario redefinir las reglas de diferenciación social, étnica y de género, reglas de convivencia y separación al mismo tiempo como la distinción de la ropa, el lenguaje, el cuidado del cuerpo, los modales, entre otros". Maribel Arrelucea Barrantes, Género, estamentalidad y etnicidad en las estrategias cotidianas de las esclavas de Lima, 17601800, Tesis de maestría no publicada, Lima: Universidad Nacional Mayor de San Marcos, 2010, p. 35.

${ }^{11}$ Entre los múltiples ejemplos destacan: «El Capitán comandante de dicha da parte al S.M. de haber dado aucilio al Ciudadano D. Juan Manuel Recabarren; el cual dice ser...»; «Promobido por d. Melchora Morales, y Tadeo Valencia sobre la declaratoria de pobreza de ambos por oposición que han hecho». ARAr, Corte Superior, Criminales, Leg 2 (1826-I); «Doña María Antonia Dias del Olmo vecina de esta ciudad, muger legítima de don Manuel Altarraga», Archivo Arzobispal de Arequipa (AAA), Curia diocesana, Fuero eclesiástico, Nulidad de matrimonios, Leg. 8.

${ }^{12}$ Alberto Flores Galindo, "La ciudad sumergida. Aristocracia y plebe en Lima, 1750-1830". En: Obras completas. Lima: Sur, Casa de Estudios del Socialismo, tomo 3, parte 2, 2010.
} 


\section{AMERICANISTAS}

\section{César Belan}

La violencia cotidiana como mecanismo de integración y ascenso social. El caso de Arequipa a fines del Virreinato. 1784-1824.

\section{ISSN 1988-7868}

su magnitud era pequeña. Del mismo modo, se extendió el uso de apelativos como don y doña. ${ }^{13}$

Esta «isonomía» de la sociedad arequipeña posibilitó que se estableciese vínculos muy profundos y cercanos entre individuos de los diferentes estratos de las clases populares, lo que moldeó de manera peculiar la cultura de la ciudad hasta bien entrada la República. ${ }^{14}$

Así pues, la configuración social y la bonanza económica permitió que Arequipa se constituyera en un lugar de mayor fluidez social, si la comparamos con otras regiones. La flexibilidad propia de una sociedad sucesivamente reconfigurada en su demografía, se tradujo en amplios espacios de promoción ciudadana para artesanos y comerciantes. Posiblemente, también la plebe mesocrática se veía estimulada por el ejemplo de la élite de nuevo cuño que se instaló en la ciudad. Gentes que, como ocurría con los inmigrantes vascos, conciliaron labores en el comercio y la industria -típicas de las clases plebeyascon su especial privilegio de hidalguía universal. Es más, los recursos que la clase privilegiada había acumulado por la actividad mercantil habían finalmente acrecentado aún más su nobleza. Consideramos que esto, sumado al hecho que por la difusión de las ideas ilustradas la Corona dispuso se considerase como oficios honrados a las «viles ocupaciones manuales», generó en la plebe arequipeña la impresión que la movilidad social era una realidad más o menos cercana. ${ }^{15}$

\section{El honor y el ordenamiento social.}

El honor constituyó un asunto fundamental para la sociedad de Antiguo Régimen. Su pérdida implicaba la muerte moral y hasta algunas veces física. Como lo señalaba la

\footnotetext{
${ }^{13}$ Fernando Calderón, op. cit., p. 71. Sin embargo, cabe hacer la salvedad que el caso arequipeo no es singular en este aspecto, a pesar de su estructura social equilibrada y pareja. En el orbe indiano de mediados y finales del dieciocho se había generalizado el uso del "don" y la lucha por el espacio simbólico de las clases habitualmente relegadas de la noción de honor hacían gala de poseerlo. Verónica Undurraga, Los rostros del honor. Normas culturales y estrategias de promoción social en Chile colonial, siglo XVIII. Santiago de Chile: Dirección de Bibliotecas Archivos y Museos (Dibam), Centro de Investigaciones "Diego Barros Arana", Editorial Universitaria, 2013.

${ }^{14}$ Chambers, op. cit.

${ }^{15}$ Carlos III promulgó la honradez de todos los oficios mecánicos en una Real Cédula del 18 de marzo de 1784.
} 


\section{AMERICANISTAS}

\section{César Belan}

La violencia cotidiana como mecanismo de integración y ascenso social. El caso de Arequipa a fines del Virreinato. 1784-1824.

\section{ISSN 1988-7868}

doctrina teológica imperante, «tres homicidios avia, y que todos tres merecian fer caftigados con la mefma pena. El primero, quitar la vida. El fegundo, aborrecer al proximo. El tercero, quitarle la fama y buen nombre». ${ }^{16}$

Arequipa no era la excepción con respecto a estas nociones sobre el honor. Es más, esta ciudad encuadrada en la periferia del mundo hispánico era conocida por el alto sentido del honor que poseían sus habitantes. Este hecho se ilustra bien por una historia relatada por Bernardino Fernández de Velasco, más conocido como el Duque de Frías (1743), en su «Deleite de la discreción y la fácil escuela de la agudeza»:

En Arequipa, ciudad de gran probeza en el Perú, y de tal vanidad de sus Vecinos, que por ella se dice aquel Proverbio: De dones, pendones y muchachos sin calzones. Sucedió que llegando á apearse en la posada cierto religioso grave, vió un mozuelo hecho andrajos, díxole:-Há mancebo, tenme este estrivo. Respondióle enfurecido: -Há Padre, sabe que habla con N. de tal, y de tal?, arrojándole millones de apellidos; á lo que dijo el religioso: -Pues señor don fulano de tal, y tal, y tal, vuestra merced vístase como se llame o llámese como se vista. ${ }^{17}$

Ya refiriéndonos a otro aspecto, es necesario señalar que el uso indistinto de términos afines como «honor», «fama» $\mathrm{y}$ «honra» han generado no pocos problemas para los estudiosos. Es así que un buen número de ellos han tratado de deslindar estos términos en las sociedades pre-modernas. ${ }^{18}$ En ese sentido, es posible diferenciar algunas fases con respecto al sentido dado a esos términos. En un primer momento la noción de «honra» estaba supeditada al estrato noble por cuna o dignidad. Luego, desde el siglo XII, el concepto sería extendido como una cualidad moral inherente a toda persona, entendiéndose ésta como la posesión de virtudes políticas. Esta generalización del

\footnotetext{
${ }^{16}$ Bartholome de Medina, Breve instrvction de como se ha de adminiftrar el facramento de la penitencia.... Huesca: Cafa de Ioan Perez de Valdivielfo, 1581, p. 144.

${ }^{17}$ Bernardino Fernández de Velasco, Deleite de la discreción y fácil escuela de la agudeza. Madrid: Oficina de Franciscos Lorenzo Moxados, 1743, p. 83.

${ }^{18}$ Carlos Maitza Ozcoidi, "La definición del concepto del honor. Su entidad como objeto de investigación histórica”. Espacio, Tiempo y Forma, Serie IV, Historia Moderna, n8 (Madrid,1995), pp. 191-209.
} 


\section{AMERICANISTAS}

\section{César Belan}

La violencia cotidiana como mecanismo de integración y ascenso social. El caso de Arequipa a fines del Virreinato. 1784-1824.

\section{ISSN 1988-7868}

término «honra» supuso la puesta en uso del vocablo «honor», que, distinguiendo entre órdenes sociales, aludía específicamente a la calidad aristocrática relacionada a la dignidad o al mérito. ${ }^{19}$ Finalmente, ya en el siglo XVI, una vez más estos términos se asocian y se usan indistintamente, algo que se aprecia en el diccionario de Covarrubias en el que se equipara ambos términos. ${ }^{20}$ En las fuentes criminales arequipeñas, aunque el uso de los términos es indistinto, prevalece la noción de «honra» como atributo personal y moral, susceptible de ostentación y defensa por parte de la masa plebeya.

El honor poseía una doble faz. En el ámbito psicológico y subjetivo otorgaba coherencia y estabilidad a la identidad. En el ámbito externo servía como salvoconducto para la vida social. Este aspecto es llamado por Maitza «honor de permanencia», y supone la posesión de una mínima parte del paradigma público «imprescindible para afianzarse en el seno de una colectividad social, y deriva de la participación en una estructura ideológica compartida y del acatamiento de una serie de valores imperantes». ${ }^{21}$

Por otro lado, y más allá del menoscabo simbólico que suponía la pérdida del honor, el ser despojado de la buena fama implicaba muchas veces menoscabos concretos y puntualmente peligrosos para la integridad de quien sufría la injuria e incluso para sus familiares y vecinos. ${ }^{22} \mathrm{Al}$ respecto las fuentes criminales arequipeñas nos ofrecen numerosos ejemplos de pleitos entre comerciantes, ${ }^{23}$ herreros ${ }^{24}$ y escribanos, ${ }^{25} \mathrm{u}$ otros oficios plebeyos. ${ }^{26}$ En estas causas, leemos cómo maestros y oficiales se ofenden

\footnotetext{
19 Marta Madero, Manos violentas, palabras vedadas. La injuria en Castilla y León (siglos XIII-XV). Madrid: Taurus, 1992; Iñaki Bazán, Delincuencia y criminalidad en el País Vasco en la transición de la Edad Media a la Moderna. Vitoria-Gasteiz: Servicio central de publicaciones del Gobierno Vasco, 1995. ${ }^{20}$ Sebastián de Cobarruvias, Tesoro de la Lengua Castellana o Española. Madrid: Luis Sánchez, Impresor del Rey N.S., 1616, pp. 952-953.

${ }^{21}$ Maitza. op. cit, p. 194.

${ }^{22}$ Bazán, op cit. p. 242.

23 «Rafael Contreras contra Agustín Herrera, por Injurias, reales, verbales y personales», 29 de enero de 1792, Arequipa, Archivo Regional de Arequipa (ARAr), Intendencia, Criminal, leg. 85.

${ }^{24}$ «El maestro Herrero Eugenio Escalera contra su oficial Pedro Cornejo, por injurias», 11 de agosto de 1811, Arequipa, ARAr, Intendencia, Criminal, leg. 90.

25 «Pedro Felipe Salazar contra Vicente Vílchez por calumnia», 21 de enero de 1795, Arequipa, ARAr, Intendencia, Criminal, leg. 85.

${ }^{26}$ Algo similar plantea Moral Roncal en su trabajo sobre la península en el mismo periodo «En nuestra opinión, a partir de la apertura de demandas judiciales, los agremiados buscaron también el reconocimiento de la honradez de sus oficios por parte de las autoridades» Antonio Moral Roncal "Honor, vileza y honra
} 


\section{AMERICANISTAS}

\section{César Belan}

La violencia cotidiana como mecanismo de integración y ascenso social. El caso de Arequipa a fines del Virreinato. 1784-1824.

\section{ISSN 1988-7868}

recíprocamente aludiendo a la inhabilidad en su empleo u otras características propias de su profesión, algo que los injuriados resentían profundamente. Esto se debía a que, al cuestionarse la pericia del artesano se afectaría también al su ingreso económico, posición social, y hasta la subsistencia del mismo. Para ello es fundamental tener en cuenta que, al no prevalecer el criterio de la economía mercantilista de nuestros días, la lógica de intercambio estaba regida por una economía aristocrática de tipo moral, basada sobre todo en el crédito y la confianza en la que el honor funcionaba como una suerte de «capital simbólico». ${ }^{27}$

Simples insinuaciones que cuestionaban la fama de una persona podrían, luego, tener desastrosas consecuencias. Este también es el caso de las esposas acusadas como infieles mediante corrillos y rumores, algo que las exponía a sufrir maltratos a manos de sus $\operatorname{maridos}^{28}$. Algo así ocurriría con la costurera María Núñez en 1787. Cuando Juana Bernal expresó de ella: «Dios me libre de Jente soldadesca» en una alusión muy velada sobre cierto consocio que mantendría Núñez con un soldado, ella manifestó que temía que «de esta infamia resulte el grabe perjuicio ó de que me mate bolviendo mi marido, ó cuando

de los oficios mecánicos en el siglo XVIII”. Baética: Estudios de arte, geografía e historia, n 18, (Málaga, 1996), p. 32. De igual manera en el París del dieciocho: «A journey-man baker, insulted in the street by the wife of a nearby innkeeper, said that her calumnies could prevent him for finding work in future because of impression they might make on people who didn't know him well [...] he claim, to make him lose most of his clients». David Garrioch, "Verbal insults in eighteenth-century Paris". En: Peter Burke y Roy Porter (eds.), The social History of language. Cambridge: Cambridge University press, 1987, p. 113.

${ }^{27}$ Pierre Bourdieu, El sentido práctico. Buenos Aires: Siglo XXI Editores, 2007. Así pues, en 1824, dos sastres, el oficial Ignacio Benavides y el maestro Mariano Goyzueta promovieron una de estas largas y costosas causas. El afectado describiría el perjuicio sufrido en los siguientes términos: «yo soy un maestro público de sastrería, en que varias personas de primero rango de esta Ciudad depositan la confianza de sus obras en mi persona, sin reselar famas de mi manejo y conducta; y si yo dejo pasar la exprecion de aquel mal hombre ya mi reputación cae por tierra, y mi honra vendría a quedar en descubierto para que nadie medé una sola obra fuera del consepto público en que seré reputado» «Ignacio Benavides contra Mariano Goyzueta por injurias verbales», 20 de agosto de 1824, Arequipa, ARAr, Intendencia, Criminal, leg. 92, fol. $1 \mathrm{y}$ v. Algo semejante menciona Verónica Undurraga analizando el espacio chileno: «Así, los comerciantes -desde los sencillos administradores de bodegones hasta aquellos dedicados al comercio a gran escala- empleaban estratégicamente las representaciones de honor como civilidad que favorecía el desarrollo de la actividad mercantil. Por su parte, peones y gañanes alimentaban el honor personal haciendo gala de sus capacidades pugilísticas y de sus conquistas amorosas». Undurraga, op. cit. p. 23.

${ }_{28}^{28}$ María del Carmen García Herrero, "La marital corrección: un tipo de violencia aceptado en la Baja Edad Media”. Clío \& Crimen, $n^{\circ} 5$ (Durango, 2008), p. 56. 


\section{AMERICANISTAS}

César Belan

La violencia cotidiana como mecanismo de integración y ascenso social. El caso de Arequipa a fines del Virreinato. 1784-1824.

\section{ISSN 1988-7868}

menos me abandone con un Diborcio perpetuo, si llegando a su noticia las expresiones ofencibas, no llegase al mismo tiempo la justificación demi inosencia». ${ }^{29}$

El ataque al buen nombre tenía, pues, implicancias simbólico-morales, políticas y económicas. La honra, pues, se mostraba como el presupuesto básico de la sociabilidad, y la piedra angular sobre la cual se ordenaba las relaciones humanas en la ciudad. Asimismo, el ataque al honor no constituiría únicamente un agravio personal, sino también era fuente de menoscabo público al representar una tentativa de alteración social de las jerarquías y valores comunitarios. La salvaguarda del buen nombre, por otra parte, será más recelada por las clases populares -tanto emergentes como por los propietarios en decadencia- ya que este patrimonio simbólico constituía parte importante de sus recursos, al estar apartados de los de orden patrimonial ${ }^{30}$.

\section{La injuria como mecanismo de ascenso social. ${ }^{31}$}

Abocándonos a la violencia en la ciudad, destacamos los diversos testimonios que afirman su carácter pacífico. En ese sentido, el gobernador intendente Antonio Álvarez y Jiménez refirió reiteradamente en su relación de visita no encontrar «causas judiciales pendientes», y aún, reos en los pueblos visitados «ya por la tranquilidad y buena armonía en que todos se han encontrado y se mantienen». ${ }^{32}$ Por su parte, su sucesor, Bartolomé

\footnotetext{
29 «María Núñez contra Juana Bernal por injurias verbales», 07 de febrero de 1787, Arequipa, ARAr, Intendencia, Criminal, leg. 85, fols. 1v y 2.

${ }^{30}$ Al respecto Enríquez Fernández señala que «el rumor maledicente era el peldaño de exclusión de la exclusión populares» y que, en contraste con las clases pudientes que se enfocan en la riqueza como modo de diferenciación social, «[para] los colectivos populares y la pequeña propiedad rural, lo sensible es el honor». José Carlos Enríquez Fernández, "Lo marginal y lo grotesco. Pautas para una caracterización de las exclusiones en las culturas populares europeas y en las hegemonías políticas del Setecientos vizcaíno". En: César González Mínguez, Iñaki Bazán e Iñaki Reguera (eds.) Marginación y exclusión social en el País Vasco, Bilbao: Universidad del País Vasco, 1999, pp. 217.

${ }^{31}$ Para el desarrollo de la investigación se han consultado como fuente, fundamentalmente, alrededor de 250 causas criminales que representan el íntegro de procesos de ese tipo custodiados por el Archivo Regional de Arequipa (ARAr). Ellos están ordenados en doce legajos que están bajo la denominación de «Intendencia Criminal». Además, se consultaron 7 legajos del Archivo Arzobispal de Arequipa (AMA) que versan sobre «Causas penales», representando el íntegro de causas eclesiásticas de tipo criminal. Secundariamente, se han revisado las secciones «Cabildo», «Obispado» e «Intendencia Administrativo», del ARAr y la de «Nulidad de matrimonio» del AMA.

${ }^{32}$ Víctor M. Barriga, Memorias para la Historia de Arequipa. Relaciones de la visita al Partido de Arequipa realizada por el Gobernador Intendente don Antonio Álvarez y Jiménez 1786-1791. Arequipa: Editorial La Colmena S.A, 1941, tomo 1, p. 138.
} 


\section{AMERICANISTAS}

\section{César Belan}

La violencia cotidiana como mecanismo de integración y ascenso social. El caso de Arequipa a fines del Virreinato. 1784-1824.

\section{ISSN 1988-7868}

María de Salamanca, destacará en su relación de gobierno «la religiosidad y sencillez de sus moradores», mencionando que «fue muy raro el homicidio perpetrado en los grandes despoblados de tan dilatada provincia». ${ }^{33}$ Finalmente, viajeros que visitaron la ciudad en la última década del S. XVIII serían de igual opinión. En ese sentido, el viajero alemán Tadeo Haenke, mencionaría que «los delitos dominantes de la plebe no son de consideración, por ser toda aquella gente apacible y de buena inclinación». ${ }^{34}$ A pesar de ello, resalta la magnitud de enfrentamientos interpersonales de carácter leve a moderado que se manifiestan en los documentos judiciales. Resalta así la gran cantidad de causas por injurias reales o verbales promovidas en la ciudad (57.3\%). ${ }^{35}$

Tabla1. Total de causas criminales (según denuncia)

\begin{tabular}{|c|c|c|c|c|c|c|c|c|}
\hline \multirow{3}{*}{$\begin{array}{l}\text { Años } \\
1784-1788\end{array}$} & \multicolumn{2}{|c|}{ Violencia interpersonal } & \multicolumn{4}{|l|}{ Otros delitos } & \multirow{2}{*}{\multicolumn{2}{|c|}{ Total }} \\
\hline & $\begin{array}{l}\text { Homicidio y } \\
\text { aborto }\end{array}$ & $\begin{array}{l}\text { Injurias } \\
\text { personales }\end{array}$ & $\begin{array}{l}\text { Contra el } \\
\text { patrimonio } \\
\text { y fraudes }\end{array}$ & $\begin{array}{l}\text { Estupro } \\
\text { y afines }\end{array}$ & $\begin{array}{l}\text { Contra la } \\
\text { Corona }\end{array}$ & Adulterio & & \\
\hline & $1 \quad(5.9 \%)$ & $12 \quad(70.6 \%)$ & $(12 \%)$ & $0 \quad(0 \%)$ & $2 \quad(12 \%)$ & $0 \quad(0 \%)$ & 17 & $(5 \%)$ \\
\hline $1789-1793$ & $3 \quad(9.4 \%)$ & $18 \quad(56.3 \%)$ & $(22 \%)$ & $1(3 \%)$ & $(6 \%)$ & $1 \quad(3 \%)$ & 32 & $(10 \%)$ \\
\hline $1794-1798$ & $3 \quad(12.5 \%)$ & $13(54.2 \%)$ & $(21 \%)$ & $1(4 \%)$ & $(8 \%)$ & $0 \quad(0 \%)$ & 24 & $(7 \%)$ \\
\hline $1799-1803$ & $5 \quad(13.9 \%)$ & $50.0 \%)$ & $10 \quad(28 \%)$ & $0 \quad(0 \%)$ & $1 \quad(3 \%)$ & $2(6 \%)$ & 36 & $(11 \%)$ \\
\hline $1804-1808$ & $6 \quad(10.0 \%)$ & $29 \quad(48.3 \%)$ & $(12 \%)$ & $1(2 \%)$ & $16(27 \%)$ & $1 \quad(2 \%)$ & 60 & $(18 \%)$ \\
\hline $1809-1813$ & $4 \quad(7.7 \%)$ & $32 \quad(61.5 \%)$ & $11(21 \%)$ & $1 \quad(2 \%)$ & $(6 \%)$ & $1 \quad(2 \%)$ & 52 & $(16 \%)$ \\
\hline $1814-1818$ & $5 \quad(7.7 \%)$ & $42 \quad(64.6 \%)$ & $(12 \%)$ & $3(5 \%)$ & $(9 \%)$ & $1 \quad(2 \%)$ & 65 & $(20 \%)$ \\
\hline $1819-1824$ & $3 \quad(8.6 \%)$ & $20 \quad(57.1 \%)$ & $(14 \%)$ & $0 \quad(0 \%)$ & $6 \quad(17 \%)$ & $1 \quad(3 \%)$ & 35 & $(11 \%)$ \\
\hline Total & $30 \quad(9.3 \%)$ & $184(57.3 \%)$ & $55 \quad(17 \%)$ & $7(2 \%)$ & $38 \quad(12 \%)$ & $7 \quad(2 \%)$ & 321 & \\
\hline
\end{tabular}

Fuente: ARAr, Intendencia, Criminal. Legajos 85-91. (1784-1824). Elaboración:

Propia.

\footnotetext{
${ }^{33}$ John Fisher, Arequipa 1796-1811. La relación de gobierno del Intendente Salamanca. Lima: Seminario de Historia Rural Andina y Universidad Nacional Mayor de San Marcos, 1968, p. 39.

${ }^{34}$ Thadeus Haenke, Descripción del Perú. Lima: Biblioteca Nacional del Perú, 1830, p. 189.

${ }^{35}$ Véase tabla $\mathrm{n}^{\circ} 1$. A pesar que es preciso relativizar estas cifras, manifestamos que existe una relación entre la particular disposición social de ese período y la gran cantidad de causas por injurias que se promovieron. Sobre la necesidad de relativizar el número de injurias por la naturaleza de las fuentes criminales: Ricardo Córdoba la Llave, "Violencia cotidiana en Castilla a fines de la Edad Media". En: José Ignacio de la Iglesia Duarte (coor.), Conflictos sociales, políticos e intelectuales en la España de los siglos XIV y XV, XIV Semana de Estudios Medievales. La Rioja: Gobierno de La Rioja e Instituto de Estudios Riojanos, 2004, pp. 393-444.
} 


\section{AMERICANISTAS}

\section{César Belan}

La violencia cotidiana como mecanismo de integración y ascenso social. El caso de Arequipa a fines del Virreinato. 1784-1824.

\section{ISSN 1988-7868}

En este punto se hace necesario preguntarnos si las injurias son algo más que simples efusiones irracionales de ira en un contexto determinado. ¿Por qué las injurias son, por lejos, el delito más promovido en Arequipa? ¿Qué impulsaba a los vecinos a enzarzase en interminables pleitos por tan sólo un gesto o una palabra mal dicha? ¿Por qué miembros de la alta y baja plebe dedicaban considerables sumas en causas que duraban años y que casi siempre terminaban en amonestaciones y reconvenciones a la conciliación? ¿Es que acaso sus patrones de comisión, tan esquemáticos hasta el punto de parecer ritualizados, esconden alguna racionalidad política?

Como se ha adelantado en líneas precedentes, las fuentes evidencian que los conflictos y posteriores juicios por injurias se concentran en el ámbito plebeyo. Artesanos, chicheras, pequeños comerciantes, minifundistas y otros plebeyos de mediano patrimonio serán los más comunes actores de los hechos de injurias y, sobre todo, los más activos promotores de las causas derivadas de ellos. De la lectura de los papeles criminales podemos observar cómo, mediante la «representación» de su honor en las disputas públicas y la «re-escenificación» del mismo en las causas judiciales, los miembros de este sector buscarán el reconocimiento social promoviendo procesos. Esto a pesar que, casi en su totalidad, estas causas serían finalmente relegadas sumariamente y en muchos casos conciliadas a la fuerza por la autoridad, a pesar de la insistencia de las partes interesadas quienes recurrían a la justicia con obstinación que rayaba en el desacato. ${ }^{36}$ Consideramos, por tanto, que la calle y el tribunal serán una suerte de arenas públicas donde se disputará el ascenso jerárquico.

Los testimonios judiciales nos llevan a pensar que la violencia urbana en la sociedad tardovirreinal arequipeña respondería a un patrón de conflicto relacional en base a dinámicas de inclusión/exclusión. Dado que los niveles jerárquicos de la ciudad eran

\footnotetext{
${ }^{36} \mathrm{El}$ poco celo para perseguir las injurias por parte de la Justicia se evidenciaba también en la normativa. Así pues, la ley IV, título X del libro VIII de la Recopilación y la ley III, título XXV, libro XII de la Novísima mandaban que: «que las Justicias de nuestros reinos sobre palabras livianas que pasaren ante cualesquier vecinos de cualesquier ciudades, villas y lugares de ellos, si no intervinieren armas ni efusión de sangre, o en que no hobiere queja de parte, o que si se hubiere dado queja se apartaren de ella y si fueren amigos, no se entremetan a hacer pesquisa sobre ello de su oficio, ni procedan contra los culpados ni alguno de ellos». Resalta el contraste entre la poca importancia que los agentes de justicia prestan a las injurias y el ahínco que manifiestan los agraviados en perseguirlas.
} 


\section{AMERICANISTAS}

\section{César Belan}

La violencia cotidiana como mecanismo de integración y ascenso social. El caso de Arequipa a fines del Virreinato. 1784-1824.

\section{ISSN 1988-7868}

imprecisos al estar permanentemente reconfigurados por las sucesivas migraciones, y siendo los criterios de ordenación social como la etnia o riqueza eran ambiguos o muy parejos, consideramos que Arequipa era un lugar susceptible de generar altos niveles de disputas por el posicionamiento jerárquico, algo que explica el alto número de injurias. Evidentemente, esto generaría potenciales conflictos de representación de los roles. Dicho de otro modo, se operaría una pugna cuando la representación de un otro confrontara la propia performance, cuando se pretendiera la diferenciación de la gran masa plebeya.

La tesis antes planteada se hace manifiesta al analizar la estructura de la disputa típica entre los vecinos arequipeños de finales del s. XVIII: un altercado producido por la puesta en cuestión de la condición social de uno de los involucrados -a pesar que el provocador también poseía un estatus incierto-, lo que finalmente desencadenaba un episodio de violencia física y verbal que tendía a la exhibición e imposición de la supuesta preeminencia jerárquica de ambos rivales ${ }^{37}$.

Como uno de los numerosos ejemplos que ilustran lo referido anteriormente, podemos citar la causa entre el sargento retirado José María Beltrán contra Domingo Arias, teniente alcalde de Yanahuara. El alcalde sería cuestionado en reiteradas ocasiones por el sargento, quien ponía en duda cualidades para ostentar el cargo, comparándolos con sus propios méritos en el campo de batalla. En ese sentido el militar referiría: «que á otros más altos que él los había sobado, y que [Beltrán] hera un Chuchón y Maricón [...] que se cagaba en todos, que hera Sargento de Campaña y tenía mas servicios que dn. Domingo [...] les dijo hiba dentrarse al Quartel con el fin solo de acabarlos a sablazos». ${ }^{38}$

Creemos que, detrás de la injuria proferida en este ejemplo, subyace un intento de relocalizarse en la escala social, a costa de la honra del injuriado. Estrategia que a la vez

\footnotetext{
${ }^{37}$ Algo que Verónica Undurraga califica como honor agonal, es decir, el que se exhibe en una suerte de ritual de violencia. Undurraga, op. cit. 349 y ss.

38 «Heridas contra Domingo Arias por José María Beltrán», 18 de marzo de 1822, Arequipa, ARAr, Intendencia, Criminal, leg. 92, fol. 3v.
} 


\section{AMERICANISTAS}

César Belan

La violencia cotidiana como mecanismo de integración y ascenso social. El caso de Arequipa a fines del Virreinato. 1784-1824.

\section{ISSN 1988-7868}

supone una velada crítica sobre el acceso a las dignidades y cargos, no en razón a sus méritos, sino mediante otros procedimientos subalternos. ${ }^{39}$

En vistas a profundizar sobre las dinámicas de rol y el delito de injurias en Arequipa nos atendremos a la propuesta de Erving Goffman. Este sociólogo norteamericano plantea que la actividad social puede definirse en función a una serie de «códigos o marcos de significación, mediante los cuales, en los rituales de interacción, se produce el encuentro entre las microestructuras de significado que componen la expresión de la persona» ${ }^{40}$. Tenemos luego que los «microprocesos» de violencia pueden orientarse a replantear la imagen personal frente a la sociedad mediante un juego de roles (performance), esto como parte de las estrategias de re-significación social que pretende la persona en su entorno. ${ }^{41}$ Los episodios de injurias y los desenlaces procesal ulteriores servirían pues como un medio de reforzar o reconfigurar la imagen proyectada de un individuo (self), apoyándose en los patrones estandarizados de comportamiento (frameworks of understanding). Hablamos pues de espacios -o mejor convendría decir teatros- en los que los miembros de una localidad escenifican su rol social para obtener o mantener estatus, utilizando los patrones jerárquicos aceptados en la comunidad. ${ }^{42} 43$

\footnotetext{
${ }^{39}$ Madero, en su análisis de las injurias en la Castilla bajomedieval, afirma que la injuria sólo podía realizarse entre iguales. Así pues, ésta no pretende romper la estructura jerárquica como tal. En ese sentido, resulta relevante que la Arequipa de fines del XVIII, tan homogénea socialmente, sea un lugar de particular comisión de injurias, las que no conllevan un discurso subversivo del orden estamental, sino configuran una estrategia de relocalización dentro de este orden. Madero, op. cit. p. 34. Algo similar menciona Verónica Undurraga en su análisis del caso chileno. Undurraga. Op. cit. p. 266.

${ }^{40}$ Aquiles Chihu y Alejandro López, "El Enfoque Dramatúrgico en Erving Goffmann". Polis. Investigación y Análisis Sociopolítico y Psicosocial, $n^{\circ} 2$ (Itzapalapa, 2000), p. 239.

${ }^{41}$ Por otro lado, sin apartarnos del modelo de los roles de Goffman, tenemos en cuenta la teoría de Charles Tilly que explica este fenómeno desde la «Interacción Social». En ese sentido, él propone el análisis de los micro mecanismos de violencia entendidos estos como «causas en escalas pequeñas que harán posibles procesos de violencia, originados a partir de «combinaciones y secuencias de mecanismos que producen efectos similares a través de amplios espectros de circunstancias»

Charles Tilly, The politics of collective violence. Cambridge: Cambridge University Press, 2007, p. 20.

${ }^{42}$ En otros rincones del Perú, como Lambayeque, encontramos similares mecánicas de conflictividad que escondían una pugna por la relocalización en el escalafón social: «ninguna etnia de los estratos inferiores, quería estar en el escalón más bajo, y la pugna por demostrar quién avanzó un poco más alto se manifiesta en los múltiples conflictos entre indios, negros y mestizos» Juan Carlos Chávez Marquina, “Delincuente o disconforme? clasificación social del delito en Lambayeque, 1780-1821”, Historia y Región, n 2 (Lima, 2014), p. 214.

${ }^{43}$ De manera diferente operará la lógica de los crímenes más violentos -sustraídos casi siempre del escrutinio público- y en los que han mediado consumo de alcohol. En ellos los autores parecen desafiar
} 


\section{AMERICANISTAS} El caso de Arequipa a fines del Virreinato. 1784-1824.

\section{ISSN 1988-7868}

Si bien existía una dimensión económica en la violencia -entendida esta como «la pugna por la escasez de recursos o la hostilidad del medio» ${ }^{44}-$, esta sólo operaba como detonante ya que el cálculo propiamente económico normalmente se dejaba de lado. Muestra de ello son los ya mencionados enormes gastos en que ambas partes incurrían para dejar sentado, una vez más y ya en el proceso, su superioridad moral sobre su oponente. Esto desplaza el foco del conflicto del ámbito económico al socio-cultural.

Las causas judiciales, como antes hemos adelantado, podían constituir también un mecanismo de representación y reposicionamiento en la escala social. Así pues, y a pesar que el aparato judicial del Antiguo Régimen se sustentaba en la asimetría de los contendientes en base de su honor ${ }^{45}$, estos - paradójicamente- servirían también como un medio cuestionador de la jerarquía, ya que por medio de una disposición judicial como un auto o sentencia se podía dejar sentado el «mayor valer» de un ciudadano, obligándose a la parte vencida su reconocimiento. ${ }^{46}$ Aunque, como ya señalamos, en la práctica la mayoría de los fallos y resoluciones de los intendentes se orientaron a mantener el statu quo, tratando de abstenerse de reconfigurar las jerarquías, en algunos casos la decisión judicial redundó en una abierta declaración de la mayor categoría de un individuo.

principalmente la sociedad jerarquizada. Gerardo Castillo Guzmán, El Alcohol en el sur andino. Embriaguez y quiebre de jerarquías. Lima: Pontificia Universidad Católica del Perú, 2015.

${ }^{44}$ Nelson Arteaga Botello, «Repensar la violencia. Tres propuestas para el siglo XXI». Trayectorias. $\mathrm{n}^{\circ} 23$, (Monterrey, 2007), p. 49.

${ }^{45}$ En una sociedad de antiguo régimen, tanto el proceso y el aparato judicial estaban signado por los códigos del honor. Dos consideraciones tendrán cabida al respecto: los antecedentes de las partes involucradas servían como prueba indiscutible para apoyar la veracidad de sus alegatos; y por otro, estaban más penadas las injurias proferidas por un subalterno en contra de su superior social (por tratarse de un atentado contra los roles y jerarquías que soportaban la coexistencia social), tratándose así de una justicia entre desiguales como ya lo señalara la ley 21. tit. 9 de la séptima partida: «porque las personas \& los fechos dellas no son contados por yguales». Al respecto, contamos en Arequipa con numerosos ejemplos de escritos en que las partes cuestionan los procesos promovidos por sus contrincantes y sus dichos, amparándose en la diferencia de honor que media entre ellos.

${ }^{46}$ El patetismo de las descripciones de las injurias sufridas que encontramos en las querellas criminales que han hecho que algunos estudiosos las cuestionen como fuentes catalogándolas de exageradas- puede ser interpretado como una reminiscencia de la «puesta en escena» de la honra que se consideraba fundamental en la lógica de exhibición del honor que predominó en la baja Edad Media. Madero, op. cit. p. 51. 


\section{AMERICANISTAS}

\section{ISSN 1988-7868}

Esta estrategia de relocalización social de los vecinos de la ciudad se tradujo, por su parte, en la proliferación de abogados y escribanos. La gran cantidad de ellos y la afición de los arequipeños a las causas judiciales quedará registrada por las líneas que el párroco vizcaíno Domingo Zamácola dedicara al respecto en 1804, y que otros cronistas han repetido:

Tenemos más críticos de capa y espada que en Turín; más doctores que en Salamanca y más abogados que el Colegio de Madrid. De estos últimos se cuentan en el día 57 en el casco de la ciudad; y por ello no es de admirar que esta demasía en dicha facultad, que se ha hecho y constituido tan común, sea el origen de que Arequipa es el teatro, permítaseme decirlo, de los pleitos sin que país alguno le iguale. $^{47}$

\section{El significado de las injurias y paradigma de sociabilidad.}

En el ámbito del honor se entrecruzan dos dimensiones: la subjetiva/psicológica que da consistencia a la identidad del sujeto, y la comunitaria, que plantea la adhesión de esta identidad personal a una comunidad por compartir pautas y principios comunes. Así pues, siendo que ambas dimensiones se entrecruzan, es posible apreciar cómo las concepciones individuales van progresivamente moldeando el paradigma cultural a la vez que éste condiciona en parte la imagen que el individuo tiene de sí mismo. A pesar de que el propio sujeto da consistencia a su identidad por un acto de voluntad, este no deja da estar marcado -aunque mantenga la ilusión de conciencia autónoma- por los valores de su entorno. Luego, la imagen de sí mismo (self) es también una reedición del paradigma cultural en el que vive el individuo. En ese sentido, Julián Pitt-Rivers señalaba que el honor «es a la vez un sentimiento y un hecho social objetivo, por un lado, un estado moral que se desprende de la imagen que cada uno tiene de sí [...] y, al mismo tiempo, un medio

\footnotetext{
47 Juan Domingo Zamácola y Jáuregui, Apuntes para la historia de Arequipa. Año de 1804, Arequipa: Imprenta de La Bolsa, 1888, p. 5.
} 


\section{AMERICANISTAS}

\section{César Belan}

La violencia cotidiana como mecanismo de integración y ascenso social. El caso de Arequipa a fines del Virreinato. 1784-1824.

\section{ISSN 1988-7868}

de representar el valor moral de los demás: su virtud, su prestigio, su rango, y en consecuencia, su derecho a la prelación».48

Como se ha mencionado anteriormente, en el mecanismo de proyección de la imagen subjetiva un individuo (self) para sostener su estatus social ante los demás (escenificar), se hace necesario recurrir a patrones estandarizados de lenguaje simbólico (frameworks of understanding) que permitan imprimir en la mente de la comunidad (público) la imagen representada por el actor social. Estos haces de significados permitirán a fin de cuentas la eficacia de la representación al ser fácilmente reconocidos por el público y por uno mismo.

Como señala Le Goff, el análisis de las injurias permite distinguir, siempre en negativo, el paradigma de comportamiento de una comunidad. En el caso que nos ocupa hablaremos del «ciudadano honrado», epíteto encontrado en numerosas causas, mediante los querellantes aludían al prototipo de ciudadano modelo, imagen de la civilidad y convivencia política. ${ }^{49}$ Este criterio de sociabilidad, asimilado y reproducido por la comunidad, y que será desarrollado en las líneas siguientes.

\section{Ofensas verbales contra mujeres y varones.}

Con respecto a las ofensas al sexo femenino, encontramos que estas, fundamentalmente, aluden al comportamiento sexual. La voz «puta» será la más recurrente de las injurias verbales dirigidas a la mujer. Esta expresión, o sus derivaciones e hipérboles, se escuchará en todos los enfrentamientos en los que participe una mujer ${ }^{50}$. Otras expresiones, utilizadas con idéntica connotación denigrante sobre la moralidad femenina serán: «indigna», «cochina», «ramera», «perra», «callejera», «fregona», «morcilla», «choriza», «descasadora», «alcahuetona» o «fraylera». De igual manera, será usado con

\footnotetext{
${ }^{48}$ Julian Pitt-Rivers, "La enfermedad del honor". En: Marie Gautheron (ed.), El honor: Imagen de sí mismo o don de sí, un ideal equívoco. Madrid: Cátedra, 1992, p. 20.

49 Jacques Le Goff, "Prólogo". En: Marta Madero, Manos violentas, palabras vedadas. La injuria en Castilla y León (siglos XIII-XV), Madrid: Taurus, 1992.

${ }^{50}$ Sobre injurias de igual naturaleza en el París del s. XVIII: Garioch, op. cit. En Vizcaya: Andrea Grande Pascual, "El delito de injurias en la documentación procesal vizcaína a finales del Antiguo Régimen (17661841)”. Clío \& Crimen, ${ }^{\circ} 13$, (Durango, 2016), pp. 213-232.
} 


\section{AMERICANISTAS}

\section{César Belan}

La violencia cotidiana como mecanismo de integración y ascenso social. El caso de Arequipa a fines del Virreinato. 1784-1824.

\section{ISSN 1988-7868}

relativa frecuencia el término «chichera» - mujer que atiende una picantería o chicheríacomo insulto. Esto en vista del prejuicio generalizado que se tenía con respecto a este oficio; prejuicio que según las causas tenía alguna razón fundada. ${ }^{51}$

Con respecto a las injurias sexuales, Pitt-Rivers, haciendo eco a doctrinas que se remontan a Aristóteles, menciona que en las sociedades mediterráneas, la mujer aporta a la familia con su sangre «la pureza de una ascendencia sin mancha». Luego, si el honor masculino es «positivo-activo», puesto que implica lograr una hazaña o defender activamente su privilegio, el honor femenino se entiende negativa o pasivamente, es decir implica «evitar todo daño a una reputación que sus hijos, tanto varones como mujeres, heredarán [...] En tal sentido el honor-precedencia es masculino y el honor-virtud es femenino». ${ }^{52}$ Este paradigma de limpieza moral que atañía a la mujer constituyó, luego, una de las bases del sistema social en la Monarquía Hispánica, y en especial en Indias. ${ }^{53}$

En segundo término, y muy poco frecuentes en comparación a los que aluden a la moral sexual, encontramos ultrajes de índole racial. En menor medida aún, encontramos afrentas contra la mujer del tipo de: «ladrona», «canalla»o «facinerosa», o «borracha», aún en el ámbito social y de comportamiento. Finalmente, serán contadas las expresiones se orientaban a zaherir a la mujer en base a defectos físicos como «vieja»o «fiera», ${ }^{54} \mathrm{o}$ por una ocupación plebeya como «pallapadora» ${ }^{55}$.

\footnotetext{
${ }^{51}$ Alrededor del $25 \%$ de las discordias de ámbito sexual-sentimental tenían como involucradas a chicheras o dependientas de chicherías.

52 Julian Pitt Rivers, "La enfermedad del honor". Anuario IEHS. Instituto de Estudios histórico sociales, $\mathrm{n}^{\circ}$ 14, (Tandil, 1999), p. 240; Madero op. cit. p. 101 y ss.

53 «Las mujeres de la élite tenían personalidades públicas y posiciones en la esfera civil precisamente porque poseían un honor que debían mantener y pasar a la generación siguiente [...] Sin embargo, podrían sufrir pérdidas en su saldo de honor si realizaban inversiones sociales desfavorables como la pérdida de la virginidad o el embarazo por fuera del vínculo matrimonial. Ann Twinam, Vidas públicas, secretos privados. Género, honor, sexualidad e ilegitimidad en la Hispanoamérica Colonial, México: Fondo de Cultura Económica, 2009, p. 106.

${ }^{54}$ Picada de viruelas.

55 Término de origen quechua que alude a una peona del campo. «Doña Josefa Ramires contra doña Narcisa Postigo, por injurias», 12 de julio de 1815, Arequipa, ARAr, Intendencia, Criminal, leg. 90, fol. 1v.
} 


\section{AMERICANISTAS}

\section{César Belan}

La violencia cotidiana como mecanismo de integración y ascenso social. El caso de Arequipa a fines del Virreinato. 1784-1824.

\section{ISSN 1988-7868}

Con respecto a los varones la afrenta más común será la de «ladrón», con todas sus posibles variantes. Así también se cuentan otras expresiones afines como «bribón», «canalla», «usurpador», «pícaro», «facineroso». Este vocablo, constituyó, al parecer, un arquetipo de insulto. Así pues, Cobarruvias lo consigna como ejemplo en su Tesoro de la lengua española: «AFRENTA [...] Tambien fe recibe afrenta de palabra, como fi a uno le dixeffen ladron, o otra palabra de las injuriofas». ${ }^{56} 57$ En segundo término, otro insulto habitual será el referido a la etnia, asociado con el vocablo anterior. Resala el hecho que hemos advertido muy pocas las ocasiones que se denigró a un varón con términos como «maricón», «chivato» o «cornudo», es decir los que aludían al ámbito sexual, y con respecto de otras conductas consideradas antisociales como «borracho». También hemos podido registrar, pero en menor medida, ofensas del tipo «viejo». ${ }^{58}$

\section{Agresiones por origen étnico.}

Las ofensas étnicas serán, además de comunes a ambos sexos, muy habituales en cualquier enfrentamiento interpersonal. «Zambo»y «zamba» será el insulto más corriente de este tipo. Se usó también expresiones como «negro», «cholo»e «indio» con una fuerte intención ofensiva. En la gran mayoría de los altercados los involucrados harían uso de afrentas de este tipo, aludiendo a alguna característica que, dentro de las ambigüedades de la raza, posibilitara la asociación de una persona a un grupo subalterno como los negros e indios. Un ejemplo de ello será la pendencia ocurrida en 1815, entre Juan de Mata, comerciante arequipeño y su vecina doña Lorenza Escudero: «Salió doña Lorenza y le dijo

\footnotetext{
${ }^{56}$ Cobarruvias, op. cit, p. 18.

${ }^{57}$ Según Madero, las injurias entre varones en la Castilla bajomedieval estaban comprendidas en el espectro de la «falsedad» (alevoso, falso, perjurado). La injuria arquetípica era la de «traidor», algo que respondía a las relaciones personales que primaban en su contexto. Por otro lado, ofensas como la de «ladrón» se circunscribía al ámbito plebeyo, sector al que se le atribuía el estereotipo de la avaricia. Se explica, luego, como en una sociedad de Antiguo Régimen de poco relieve en el orbe hispánico como lo era la arequipeña, la ofensa más común se asocie a la afectación del patrimonio. Ciudad cuya élite estaba conformada por comerciantes ennoblecidos. Madero, op. cit. p. 133; 147. Según Undurraga, en su estudio sobre el honor en Chile, el epíteto pícaro y ladrón también era el más usual para zaherir a los varones. Undurraga op. cit. 247.

${ }^{58}$ Algo similar ocurriría en el periodo en el ámbito rural cuzqueño: Ward Stavig, "Violencia cotidiana de los naturales de Quispicanchis, Canas y Canchis en el siglo XVIII”. Revista Andina, n`3, vol. 2, (Cuzco, 1985), pp. 451-468. En Vizcaya: Grande, op. cit. pp. 213-232. En Navarra: Mikel Berraondo, La violencia interpersonal en la Navarra moderna (siglos XVI-XVII. Tesis doctoral. Universidad de Navarra, 2012. En Paris: Garrioch, op. cit., pp.104-119.
} 


\section{AMERICANISTAS}

\section{César Belan}

La violencia cotidiana como mecanismo de integración y ascenso social. El caso de Arequipa a fines del Virreinato. 1784-1824.

\section{ISSN 1988-7868}

'Perro negro como habías de tener manos para tus amos, y a lo que contesté [Juan de Mata] ¡Qué llama negro la india! Replicó entonces que a los negros se los sacaba en un aparejo, y contesté que a las indias en una llama con un costal y soga» ${ }^{59}$. A pesar que los involucrados se presentaron a la posterior causa como españoles, sus mutuas ofensas se concentrarían fundamentalmente a asuntos étnicos y a los estereotipos de incivilidad y servidumbre a los que se asociaban con estos grupos. En la injuria antes citadas se hace, pues, referencia a los paseos hechos por los reos antes del cumplimiento de su sentencia, estableciendo así relaciones entre etnia y delito.

Es curioso mencionar que las expresiones que hacían mención a la pertenencia a una etnia con evidente objetivo denigratorio, se profirieron, incluso, por miembros de ese mismo segmento étnico. Así pues, tenemos registro de indios que buscan ofender a sus pares utilizando vocablos como «cholo» e «indio». Este es el caso de Juana, hija de Petronila Bera, quien ayudaba a su madre en un establecimiento de venta al menudeo. Al ser víctima de una injuria, su madre interpondrá una querella, mencionando: «Estando mi hija Juana despachando la bendeja ${ }^{60}$ que mantengo para ayudar mi subsistencia [...] le contesto un indio cuya persona ignora, con estas palabras = Toma Chola puta esta llave...». ${ }^{61}$

Más allá de lo ya mencionado, creemos que necesario deslindar este tipo de agravios con connotación racista, algo que consideramos está más ligado al paradigma positivista del s. $\mathrm{XIX}^{62}$. En primer lugar, el concepto de raza no estaba definido en el

\footnotetext{
${ }^{59}$ «Don Juan de Mata contra doña Lorenza Escudero por injurias verbales», 01 de enero de 1819, Arequipa, ARAr, Intendencia, Criminal, leg. 92. fol. 1v.

${ }^{60}$ Vendeja: f. Venta pública y común como en feria.

61 «Da. Petronila Bera contra Manuela, María e Ignacia Santayana por injurias», 15 de abril de 1816, Arequipa, ARAr, Intendencia, Criminal, Leg. 91, fol. 1v.

62 «Le terme de «race», dans son sens usuel et actuel de «groupe ethnique qui se différencie des autres par un ensemble de caractères physiques héréditaires» selon la définition que l'on trouve dans le Robert, est tout aussi anachronique ou pour le moins peu adapté pour comprendre la structuration des sociétés anciennes du Nouveau Monde. Le concept de race et ses différents usages ont une histoire qu'il est indispensable de retracer si l'on veut l'utiliser à profit. Il est, me semble-t-il, miné par des usages fixés au XIXe siècle et polarisés autour des politiques raciales les plus contemporaines: ségrégation étatsunienne, apartheid sud-africain, lois anti-juives de Vichy en France, etc.» Arnaud Exbalin. "Des haillons et des perles. Images des inégalités socio-raciales en Nouvelle-Espagne", en: Cattherine Lacaze, Ronald SotoQuirós y Ronny Viales Hurtado (eds.) Historia de las desigualdades étnico-raciales en México,
} 


\section{AMERICANISTAS}

\section{César Belan}

La violencia cotidiana como mecanismo de integración y ascenso social. El caso de Arequipa a fines del Virreinato. 1784-1824.

\section{ISSN 1988-7868}

periodo de estudio, así pues, la diferenciación se remite más a la noción de etnia ${ }^{63}$. Los insultos que hemos citado, creemos, deberían interpretarse como conceptos culturales, y en el caso de las injurias, a alusiones al estándar de civilidad. ${ }^{64}$ El maltratar a una persona aludiendo a la pertenencia al grupo indígena o africano se refería a la condición de «minoría de edad» o de «capacidad relativa» de los indios y negros en la comunidad política. Cualquier alusión a estos segmentos, por tanto, deberá ser entendida como la denuncia a un comportamiento no arreglado a la idea de policía, cuyo estándar -al menos teóricamente- se manifestaba en el actuar de los vecinos de la República de Españoles. Se trataría, pues, de alusiones a conductas indeseadas de sectores que se consideraban «en vías de integración a una sociedad plenamente política». ${ }^{65}$

En ese sentido, Adorno reflexiona sobre la imagen que se tenía del indígena americano en el orbe hispano según el paradigma cultural vigente de la «segunda escolástica». Según la teoría de Francisco de Vitoria y la Escuela de Salamanca no se consideraba

Centroamérica y el Caribe (Siglos XVIII-XXI) San José de Costa Rica: Centro de Investigaciones Históricas de América Central, 2019, p. 5.

${ }^{63}$ Robert McCaa. "Calidad, Clase, and Marriage in Colonial Mexico. The Case of Parral, 1788-1790", Hispanic American Historical Review. No. 64, (Durham, 1984), pp. 477-501.

${ }^{64}$ Los epítetos «indio» $\mathrm{O}$ «negro» no serían, pues, raciales, sino que corresponderían a conceptos culturales (Chambers 2003). Hacemos hincapié en esto, remarcando la inexistencia de patrones «raciales» para agrupar a un individuo a una corporación o asociarlo a una determinada situación jurídica. En muchos casos esto se pone de manifiesto. Por ejemplo, en el homicidio de Antonio Raberto por parte de sus compañeros en el camino que se diría a Cuzco. En la causa, el escribano quedó confundido cuando, al inicio de la investigación se inscribió a José Garabai como español por su tez blanca y color de cabellos, al tomársele su confesión se manifestó que era quechuahablante, por lo que era fundamental hacer uso de intérprete. Esto obligó al escribano a dejar constancia del «cambio de etnia» salvando su error al aludir que le era imposible haber intuido que el citado Garabai era indígena en vista de su aspecto físico. «Por el homicidio de don Antonio Raberto, encargado de azentista general de azogues de Huancavelica», 26 de setiembre de 1800, Arequipa, ARAr, Intendencia, Criminal, leg. 87. Similares casos registra Stavig en Cuzco: «Juan de Bueaño, el español, no encajaría por su adscripción racial o étnica $[. .$.$] necesitó un intérprete para rendir su$ declaración. No era el único español en Quispicnchis y en Canas y Canchis que no podía hablar en castellano. Se ha encontrado varios de estos casos». Ward Stavig, "Ladrones, Cuatreros y Salteadores. Indios criminales en el Cuzco rural a fines de la colonia". En: Bandoleros, abigeos y montoneros. Criminalidad y violencia en el Perú, siglos XVIII-XX, Carlos Aguirre y Charles Walker (eds.), Lima: Instituto de Apoyo Agrario y P\&P, 1990, p. 99.

${ }^{65}$ Rafael Sánchez-Concha, Del régimen hispánico. Estudios sobre la conquista y el orden virreinal peruano. Arequipa: Fondo editorial de la Universidad Católica San Pablo y Centro de Estudios Peruanos, 2013. 


\section{AMERICANISTAS}

\section{César Belan}

La violencia cotidiana como mecanismo de integración y ascenso social. El caso de Arequipa a fines del Virreinato. 1784-1824.

\section{ISSN 1988-7868}

al natural americano como un ser definitivamente inferior, sino, al contrario, como poseedor de todas las facultades racionales que existían en potencia sin estar plenamente desarrolladas [...] lo que faltaba era la instrucción y la educación para que se realizaran sus potencialidades racionales [...] Esta hipótesis de Vitoria sobre el desarrollo evolutivo e histórico de mundo amerindio fue aceptada por muchos pensadores. ${ }^{66}$

Este criterio diferenciador entre «perfección ontológica» y «perfección histórica» deudora de los conceptos aristotélicos de acto y potencia- son los que sustentarán la visión que se tenía del indio como ser digno en sí mismo, pero muchas veces cultor de costumbres lejanas al ideal ciudadano pleno; situación que por otro lado debía perfeccionarse mediante la evangelización y la educación.

Así pues, haremos referencia de aquellos estereotipos de incivilidad que se les atribuía a las etnias en vías de asimilación política al cuerpo de República. En primer lugar, «se creía ampliamente que las personas de ascendencia africana -sobre todo los racialmente mixtos mulatos y zambos- eran solapadas, taimadas y proclives a la delincuencia» ${ }^{67}$. Las esclavas y negras libres «eran percibidas como sensuales, libertinas, dispuestas al sexo y el placer» ${ }^{68}$ y como una fuente de conflictos intrafamiliares, ya que solían liarse y convivir con hombres casados, algo que han confirmado en menor medida las fuentes criminales y eclesiásticas ${ }^{69}$.

\footnotetext{
${ }^{66}$ César Sánchez Martínez, “Con más nobleza que la que ha tenido el orbe entero: La vindicatio indianorum de Ventura Travada (c. 1752) y el tópico del 'racismo colonial' en el Perú". Allpanchis. Revista del Instituto de Pastoral Andina, $\mathrm{n}^{\circ}$ 77-78, (Arequipa, 2011), p. 257.

${ }^{67}$ Chambers, op. cit, p. 101. Por otro lado, Andazábal afirma que la casta más involucrada en la comisión de delitos -y especialmente atroces como el homicidio- era la africana, algo similar a lo encontrado en Arequipa, ya que los negros y castas aparecen en mayor proporción como victimarios que como víctimas. Rosaura Andazábal, Criminalística peruana en el siglo XVIII. Lima: Seminario de Historia Rural Andina y Universidad Nacional Mayor de San Marcos, 2007.

${ }^{68}$ Arrelucea Barrantes, op. cit. p.41.

${ }^{69}$ Rosaura Andazábal, Criminalística peruana en el siglo XVIII. Lima: Seminario de Historia Rural Andina y Universidad Nacional Mayor de San Marcos, 2007.
} 


\section{AMERICANISTAS}

\section{César Belan}

La violencia cotidiana como mecanismo de integración y ascenso social. El caso de Arequipa a fines del Virreinato. 1784-1824.

\section{ISSN 1988-7868}

A los indígenas, por su parte, «se les atribuía los vicios de la ociosidad, la ignorancia y ebriedad» $»^{70}$. Sobre la particular «incivilidad» que pesaba sobre los indios podemos dar cuenta de varias fuentes del periodo. Por ejemplo, Antonio de Pereyra y Ruiz, contemporáneo a la época, afirmará lo siguiente en su crónica titulada «La Noticia de Arequipa»:

Quanto mas bien se le hace [al indio] vive mas desconfiado, mas descontento, y aborrece mas al bienhechor [...] aman la ociosidad, huyen de todo trabajo [...] A dos cosas se reduce el modo de solemnizar sus grandes fiestas: la una es echar mucha polvora en Cohetes, para lo cüal gastan con gusto algun real: la otra es la borrachera, que es la que pone fin á todos sus placeres. Pero no se vé ninguno que confiese ni comulgue en tales días, ni lo hacen mas que cuando para el cumplimiento de la Iglesia son llevados a la fuerza [...] se ven llenos los Portales $y$ calles de estos hombres desnudos, durmiendo toda la tarde. ${ }^{71}$

Otro contemporáneo a este clérigo, Francisco Javier de Echevarría, manifestaría en 1804 consideraciones semejantes a la masa indígena de Arequipa:

los indios de Cayma siempre lo fueron y siempre lo serán pobres y desdichados a causa de su continua embriaguez y ociosidad para cuyo mal, no alcanzan ningunos remedios humanos. ${ }^{72}$

Ese mismo año, el párroco de este distrito indígena de la ciudad, Cayma, se expresará de sus vecinos de similar forma:

\footnotetext{
${ }^{70}$ Chambers, op. cit, p. 101.

${ }^{71}$ Enrique Carrión Ordóñez, La lengua en un texto de la ilustración. Estudio Filológico de «La Noticia de Arequipa» de Antonio Pereyra y Ruíz, 1816. Lima: Pontificia Universidad Católica del Perú, 1983, pp. 402403. En ese sentido, en la causa incoada contra don Pascual Bargas, alcalde de naturales de la parroquia de Santa Marta, al responder sobre supuestos excesos cometidos contra dos indios, respondería que «no debe tenerse en cuenta a los dichos de los naturales por su inclinacion a la vevida». «Vicente Vilca e Ysabel Condori contra don Pascual Bargas...», 13 en noviembre de 1798, Arequipa, ARAr, Intendencia, Criminal, leg. 86, fol. 6.

${ }^{72}$ Echevarría, op. cit. 251.
} 


\section{AMERICANISTAS}

\section{ISSN 1988-7868}

Su vecindario es tan sumamente perezoso, desidioso y entregado a una total ociosidad y dado a la embriaguez, especialmente desde que se cometió el yerro de quitar los repartimientos. ${ }^{73}$

Adicionalmente, estos estereotipos generaron un círculo vicioso entre los sectores relegados. Estos grupos marginados serían, luego, proclives al crimen en tanto que la propia etiqueta de marginalidad contemplaba un perfil incivil de ciudadano; estereotipo que - por otra parte- se reforzaría con la criminalidad en que incurrirían muchos individuos de estos sectores.

Finalmente, los sectores negro e indígena opondrán estos estereotipos entre ellos en su interacción cotidiana, reforzando las etiquetas disociales que pesaban entrambos. Sobre el particular el Virrey O`Higgins mencionaría que «la animadversión profesada entre ellos [negros e indios] era más fuerte que el odio a los españoles», encontrando luego que estos sectores «son irreconciliables». ${ }^{74}$

\section{El revés de las injurias: el paradigma del «ciudadano honrado».}

Para completar el panorama sobre las injurias, debemos hacer alusión a la imagen positiva que ellas proyectaban, hablamos del ideal de «policía» comúnmente llamado como el del «ciudadano honrado», paradigma de sociabilidad en que funda la vida civil. Así pues, las injurias nos brindan un amplio reportorio de conductas reñidas con el ideal de convivencia pública. En un primer lugar aluden a los paradigmas de civilidad que corresponden a los prejuicios que se tenían con respecto a algunos segmentos étnicos. Finalmente, y en el desagregado por sexo, podemos tomar cuenta de las transgresiones más importantes según la mentalidad del lugar (liviandad sexual en el caso de mujeres; y

\footnotetext{
${ }^{73}$ Domingo Zamácola y Jáuregui, "Comunicaciones del párroco de Cayma al intendente de Arequipa...". En: Apuntes para la historia de Arequipa, y otros textos.1804. Arequipa: Mejía Baca, 1958, p. 37 y s. En las causas criminales también se hace eco de ese prejuicio contra los indígenas. En el informe que haría el juez comisionado don Ysidoro Joseph Ortíz de Uriarte en una causa que promovían dos indios contra el alcalde de naturales de su jurisdicción, este señalaría: «No debe tenerse en cuenta los dichos de los naturales por su inclinación a la vevida». «Vicente Vilca e Ysabel Condori contra don Pascual Bargas, alcalde de naturales de la parroquia de Santa Marta», 13 de noviembre de 1798, Arequipa, ARAr, Intendencia, Criminal, Leg. 86, fol. 7.

${ }^{74}$ Flores Galindo, op. cit., 133.
} 


\section{AMERICANISTAS}

\section{César Belan}

La violencia cotidiana como mecanismo de integración y ascenso social. El caso de Arequipa a fines del Virreinato. 1784-1824.

\section{ISSN 1988-7868}

la deshonestidad en caso de los varones), y por oposición obtener una imagen del prototipo de ciudadano virtuoso. En el ámbito femenino hablamos de una vecina discreta, fiel y sumisa a su marido, y poseedora de una pureza sexual comprobada. El varón, por otro lado, debería laborioso, leal a la Corona y a su palabra, laborioso y respetuoso de las autoridades. Finalmente, piadosos católicos y «temerosos de Dios», en cualquiera de los dos casos. ${ }^{75}$

Por otro lado, afirmamos que este paradigma de ciudadano no será rechazado por los grupos «marginales». Antes bien, el sector plebeyo, tanto sea acomodado o no, no escatimará trabajos para adecuarse a este patrón, que cierta historiografía afecta a los binomios cerrados y enfrentados llamaría «dominante»o «hegemónica». ${ }^{76}$ Las fuentes nos ofrecen abundante información sobre los esfuerzos de la para asemejar el arquetipo de «ciudadano honrado», tarea muchas veces fallida, ya que diversas ocasiones se limitarán a imitar solamente la imagen de este prototipo. Así pues, serán habituales las causas en las que individuos de estratos deprimidos de la sociedad pretenden ostentar las calidades del «ciudadano honrado», imponiéndose a sí mismos ese apelativo ${ }^{77}$. En ese sentido, un buen número de africanos libertos se calificarían con el epítome de «don», como lo hizo

\footnotetext{
75 En su estudio del París del siglo XIX, Garrioch plantea interpretación una interpretación semejante. Garrioch, op. cit., p. 104-119.

76 «Los delincuentes indios [forasteros] eran traídos ante la justicia por otros indios [naturales de Canas, Canchis y Quispicanchis] que a menudo los veían como desadaptados, flojos y a veces peligrosos», discriminándoseles al atribuirles así las características inciviles que tanto pesaban sobre la colectividad indígena. El valor mismo de la supervivencia social -que estaba garantizado por la reproducción de las pautas de policía que permitirían la subsistencia- suponía la discriminación de aquellos comportamientos que pusieran en riesgo la estabilidad del grupo, y por tanto todos los sectores sociales echaban mano de estos «prejuicios» para manifestar su desprecio a otro. Luego, los indígenas asimilaron estos criterios de discriminación y «fortalecieron al sistema colonial al darle importancia cultural al control de la delincuencia». Stavig, 1990, op. cit., p. 82.

${ }^{77}$ Gálvez, en su estudio sobre las dispensas matrimoniales en la Toluca del s. XVIII señala: «Los códigos del honor sexual de las mujeres españolas serían una fuente de imitación para las mujeres plebeyas y de las castas». María Ángeles Gálvez Ruiz, "Dispensas, disensos y otros impedimentos a la formación matrimonial en el juzgado eclesiástico de Toluca", Temas americanistas, ${ }^{\circ}$. 40, (Sevilla: 2018), pp. 188212. Por su parte, al referirse al discurso de las esclavas limeñas del s. XVIII, Arrelucea señala: «revelan que muchas de ellas emplearon otras categorías semejantes como "virtuosas", "sin manchas", "trabajadora honrada", "sin tacha alguna", "sin motivo de queja" acentuando sus cualidades de laboriosidad y recato (...) los esclavos, a pesar de ser considerados mercancías, inferiores y pasionales, también interiorizaron y usaron estos principios». Arrelucea Barrantes, op. cit., 42; 44.
} 


\section{AMERICANISTAS}

\section{ISSN 1988-7868}

\section{César Belan}

La violencia cotidiana como mecanismo de integración y ascenso social. El caso de Arequipa a fines del Virreinato. 1784-1824.

Gregorio Carpio en su escrito de querella, además de hacer un recuento de los rasgos que atestiguaban su honra. ${ }^{78}$

Tal como se ha adelantado en líneas anteriores, el estatus de «policía» que comúnmente se asociaba a «lo hispánico», se limitó en diversas ocasiones desde el ámbito estrictamente formal, es decir a la adopción de elementos externos de esa cultura. En esa tónica, será elocuente lo manifestado por don Pascual Vargas, en un pedido dirigido al intendente:

Todos los Indios [...] quieren volverse Españoles, ya porque se visten a lo español, ya porque aprehenden oficios de Españoles, como Barberos, sastres, etc. ya porque tienen el color algo palido, ya porque se han peinado a la moda, ya porque sus Padrinos son Españoles, y los hasen baptisar en la Catedral y ya porque se mudan los apellidos de Yndio, y se ponen los de Español. ${ }^{79}$

Así pues, siguiendo en parte el esquema de Van Velsen, hemos de resaltar que en la performance social del día a día los individuos manipulan y reformulan paulatinamente el patrón cultural, es decir la versión arquetípica de la representación social. Este, pues, será asumido en parte, haciéndose hincapié en el aspecto formal-material (manifestación exterior de la cultura), abriéndose luego campo para la hibridación de pautas de comportamientos de la propia cultura con la que se reputa como oficial. Luego, las estructuras de comportamiento se muestran como permeables y porosas, y gracias a su aprovechamiento personal o reinterpretación interesada son nutridas con nuevos significados. ${ }^{80}$

\footnotetext{
78 «Don Gregorio Carpio contra Melchor Cáceres y otros, por Injurias Reales y Verbales», 24 de junio de 1809, Arequipa, ARAr, Intendencia, Criminal, leg. 89.

79 «Don Pascual Vargas representa las dificultades...», 20 de enero de 1803, Arequipa, ARAr, Intendencia, Administrativo. leg. 99.

${ }^{80}$ Jan Van Velsen, The politics of kinship. A study of social manipulation among the lakeside Tonga of Malawi. Manchester: Manchester University Press, 1964.
} 


\section{AMERICANISTAS}

\section{César Belan}

La violencia cotidiana como mecanismo de integración y ascenso social. El caso de Arequipa a fines del Virreinato. 1784-1824.

\section{ISSN 1988-7868}

En concreto, en Arequipa, observamos una nutrida gama de «re-significaciones del patrón cultural de ciudadanía», más allá de la pura asimilación de los roles establecidos. La plebe -sin abandonar su objetivo de emular el arquetipo social e integrase más sólidamente al conglomerado social para adquirir un mayor estatus- tampoco desaprovecha la oportunidad de adaptar estos modelos de ciudadanía a versiones adecuadas a sus propios patrones e intereses. Es inadecuado entonces hablar de un binomio asimilación/marginalidad de las estructuras de comportamiento. Una serie de estrategias permitirán, pues, el aprovechamiento -con la consecuente modificación- de dichos modelos por parte de sectores serviles de la población ${ }^{81}$.

Este fenómeno de particular mestizaje y de adscripción a los paradigmas culturales hispanos se denominará blanqueamiento mental, y explicará que el número de españoles en la ciudad sea tan numeroso ${ }^{82}$. En el siglo XVIII el patrón jurídico de las Dos Repúblicas había sido en buena medida sobrepasado, y que en la clasificación étnica había pesado más la lengua y la costumbre que el color de la piel. Al amparo de ello y de las ambigüedades de la raza muchos indígenas y mestizos asimilarían las costumbres españolas para luego "convertirse" en tales, fenómeno que se consumaba con el empadronamiento como españoles en los archivos parroquiales. En el espacio Novohispano, Pilar Gonzalbo describe el fenómeno afirmando que las calidades de los vecinos tendían a "mejorar" generación a generación, flexibilizándose en los párrocos los criterios de registro ${ }^{83}$. Esto último explicaría, luego, como a pesar que en los registros oficiales abundaba el número

\footnotetext{
${ }^{81}$ Un viajero que visitó Lima en 1796 mencionó al respecto: «Las demás clases de mujeres [mulatas y negras] siguen el ejemplo de las señoras así en la moda de su vestuario como en la pompa de él llegando a la suntuosidad de las galas hasta las negras con relación a su esfera. Ni éstas ni otras andan descalzas como en Quito...El aseo y primor es prenda tan general en todas que siempre andan almidonadas luciendo los follajes de encajes cada una según sus posibles» Joseph Laporte, El viajero universal o noticia del mundo antiguo y nuevo, París: s/d, 1796, p. 92. Por su parte, Joseph Ignacio de Lequanda escribió de manera similar: «El negro y demás castas pretenden la imitación del dominante y esta es la proporción que regla sus consumos en los trajes y ornatos siendo innegable el lujo que reina en estos moradores». Ignacio de Lequanda, «Discurso sobre el destino que debe darse a la gente vaga que tiene Lima», en: El Mercurio Peruano, T. X, 1794, pp. 59-62.

82 Nicolás Sánchez-Albornóz, La ciudad de Arequipa. 1573-1645. Condición, migración y trabajo indígenas. Arequipa: Universidad Nacional de San Agustín, 2003; Chambers, op. cit.

${ }^{83}$ Pilar Gonzalbo, Familia y orden colonial, México D.F: El Colegio de México, 2010.
} 


\section{AMERICANISTAS}

\section{César Belan}

La violencia cotidiana como mecanismo de integración y ascenso social. El caso de Arequipa a fines del Virreinato. 1784-1824.

\section{ISSN 1988-7868}

de «españoles», viajeros como Henrich Witt (1824) ${ }^{84}$, Eugene de Sartiges (1834) ${ }^{85}$ y Flora Tristan (1834) $)^{86}$ mencionan que, a simple vista, Arequipa era una ciudad donde abundaban indígenas y africanos y que las mujeres eran de piel morena, a pesar que en los censos abundaban los españoles.

El blanqueamiento mental y la alta movilidad social, finalmente, daría pie a una suerte de homogenización cultural, que enfatizaba la cultura hispánica (aunque en realidad evidenciaba una realidad mestiza). La difusión del castellano ${ }^{87}$, los usos y costumbres occidentales, la devoción y piedad cristiana $^{88}$ y un destacado realismo y fidelismo a la Corona ${ }^{89}$ fueron luego considerados marcadores sociales y prendas de civismo apetecidas por todos los vecinos. Valores que se relacionarían a los de la «cultura de la honra», de la que hablaremos más adelante.

Finalmente, y como consecuencia de este deseo de integración por parte de segmentos indígenas y negros -y la consiguiente emulación de manifestaciones culturales hispánicas-, españoles y mestizos que se reclaman como tales se verán amenazados. Así pues, por su lado este grupo denunciará el carácter «aparente» de la asimilación al ideal político de indios y africanos, acompañando las injurias étnicas con expresiones como «alzado», «osado», «advenedizo» $\mathrm{o}$ «afeytado». ${ }^{90}$

\footnotetext{
${ }^{84}$ Henrich Witt, Diario 1824-1890. Lima: Mass Comunicación, 1992.

${ }^{85}$ Raúl Porras Barrenechea, República Peruana y Dos viajeros franceses en el Perú republicano, Lima: Editorial Cultura Antártica, 1947.

${ }^{86}$ Flora Tristán al respecto menciona que «La población de Arequipa, comprendiendo la de los arrabales se eleva a 30 o 40000 almas, se puede considerar que se compone poco más o menos de una cuarta parte de blancos, otro tanto de negros o mestizos y la mitad de indios [...] He visto a varias señoras que pasan por blancas, aunque su piel sea color canela, porque [dicen] fue nativo de Andalucía o del Reino de Valencia» Flora Tristán, Peregrinaciones de una paria. Lima: Centro de la Mujer Peruana Flora Tristán, Fondo Editorial UNMSM, 2003, p. 286.

${ }^{87}$ «En Arequipa solo se habla la lengua castellana, pero con tanta finura, suavidad y propiedad, como en las ciudades mas cultas de España» Zamácola, op. cit., p. 6.

88 «Entre todos los Obispados del Perú es singular el de Arequipa en no tener en toda su estension indios salvajes por conquistar; porque desde el establecimiento del catolicismo en este imperio, se redujeron todos á la cristiandad y se han mantenido en ella» Zamácola, op. cit., p. 8.

${ }^{89}$ Arequipa uno de los últimos lugares donde se juraría la Independencia en Sudamérica.

${ }^{90}$ De esta manera sería agraviada Januaria Baldivia, llamada por el alcalde de Siguas D. José Antonio Martínez del Campo de «chola bribona, alzada y osada». «Causa criminal seguida por el Alcalde de Siguas D. José Antonio Martínez...», 24 de diciembre de 1815, Arequipa, ARAr, Intendencia, Criminal, leg. 91. fols. 8 y 13 .
} 


\section{AMERICANISTAS}

\section{César Belan}

La violencia cotidiana como mecanismo de integración y ascenso social. El caso de Arequipa a fines del Virreinato. 1784-1824.

\section{ISSN 1988-7868}

\section{Conclusiones.}

Por contraste a los alarmantes cuadros de violencia retratados en otros ámbitos del virreinato peruano y de la Monarquía Hispánica, Arequipa resaltaba por la baja incidencia criminal. Algo que atribuimos a las grandes posibilidades de ascenso e inclusión social que ofrecía la ciudad en el dieciocho. La bonanza económica de la ciudad impulsó a los vecinos -quienes buscaban escalar jerárquicamente- a adscribir, reproducir y representar los valores de la comunidad, galvanizándose e integrándose así la sociedad mediante la defensa de los principios comunes.

El acenso jerárquico y la participación plena en la vida de la ciudad, entrañaba la reproducción de los patrones de comportamiento y de los ideales políticos de la comunidad. En una ciudad con altas expectativas de ascenso social como lo fue la Arequipa del dieciocho, esto se podía traducir en una fuerte adscripción de los valores cívicos por parte de amplios sectores de la población. Es posible que la fuerte aculturación indígena y marcada aculturación hispánica de la ciudad y su acentuado y prolongado realismo tenga que ver con este factor ${ }^{91}$.

Según los resultados de la pesquisa, estamos en condición de afirmar que las ocurrencias de injurias, y sus posteriores causas judiciales, sirvieron como un mecanismo de reposicionamiento social en Arequipa. Mediante la ofensa pública a un «otro»se pretendió elevar o reforzar, esto mediante una dinámica performativa de la propia identidad (self) reposicionada en comparación a la condición de un subalterno. Siendo que los métodos más efectivos de ascenso social para la plebe -como el entronque matrimonial y la obtención de cargos y beneficios- eran limitados, la continua performance de la identidad, utilizando preferente la comparación (injuria), se convertirá en una manera simple e inmediata de repuntar el estatus frente a la comunidad más

\footnotetext{
${ }^{91}$ En el otro extremo, sociedades más rígidas y de élites más estables y consolidadas como la cuzqueña o la limeña, permitían un espacio de despliegue social mucho más limitado tanto para la plebe como la élite, circunscribiéndose a reproducir dos tipos de vecinos: los «integrados», es decir los dignos de honor: los indios naturales y principales en el caso de las comunidades del Cuzco; la élite peninsular y criolla en el caso de Lima); y los «marginados»: negros y mestizos relacionados con actividades de bandolerismo en Lima o en el norte del virreinato (Flores Galindo, op. cit; Andazábal, op. cit.); y los indios forasteros de las comunidades indígenas del Cuzco, quienes sobrevivían del abigeato (Stavig, 1990, op. cit., p. 451-468).
} 


\section{AMERICANISTAS}

ISSN 1988-7868
César Belan

La violencia cotidiana como mecanismo de integración y ascenso social. El caso de Arequipa a fines del Virreinato. 1784-1824.

próxima. Con las querellas promovidas por los miembros de la plebe más pudiente ocurrirá otro tanto, en sede judicial escenificarán su «mayor valer»ante la sociedad, buscando así un reconocimiento de su estatus mediante los fallos.

Detrás de las injurias encontramos que, todas ellas constituyen el anverso del paradigma de «ciudadano honrado»: modelo cívico al que debiera aspirar todo vecino. La mayor adecuación a este modelo permitiría un mayor reconocimiento social y todos los beneficios que esto conllevaba.

Finalmente, consideramos que los insultos por origen étnico no se dirigirán a destacar superioridades o inferioridades raciales. Estos más bien aludirán al paradigma de plena asimilación a la ciudadanía; algo que -según la mentalidad de la época- estaba en proceso en las etnias africanas e indianas. Así lo atestiguan el significativo número de agravios de contenido racial ejecutados por indígenas contra indígenas. 